\title{
₹US65
}

science for a changing world

\section{Eagle Mountain Mine- geology of the former Kaiser Steel operation in Riverside County, California}

By Eric R. Force ${ }^{1}$

Open-File Report 01-237

2001

This report is preliminary and has not been reviewed for conformity with U.S. Geological Survey editorial standards or with the North American Stratigraphic Code. Any use of trade, firm, or product names is for descriptive purposes only and does not imply endorsement by the U.S.

Government.

U.S. DEPARTMENT OF THE INTERIOR

U.S. GEOLOGICAL SURVEY

${ }^{1}$ U.S. Geological Survey, 520 N. Park Avenue, \#355, Tucson, AZ 85719 


\section{Table of Contents}

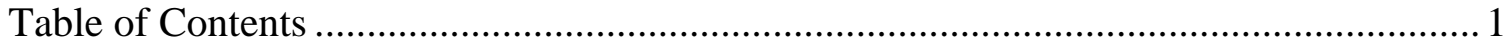

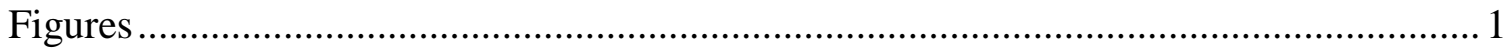

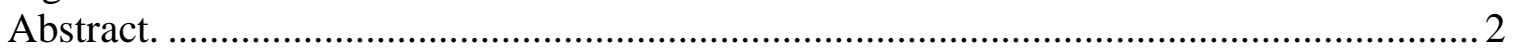

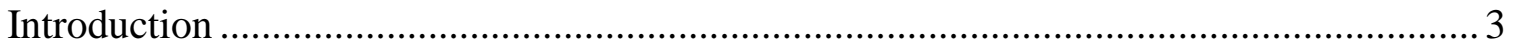

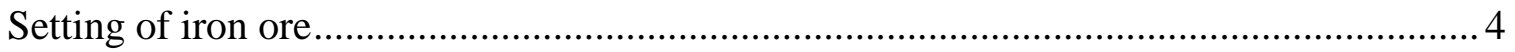

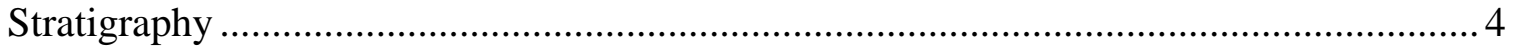

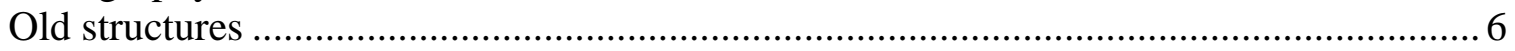

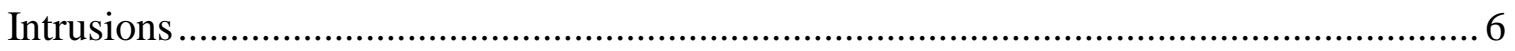

Metamorphism ............................................................................................. 7

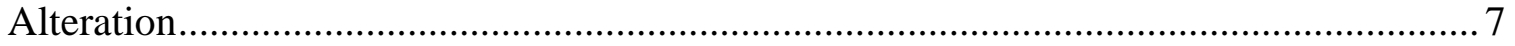

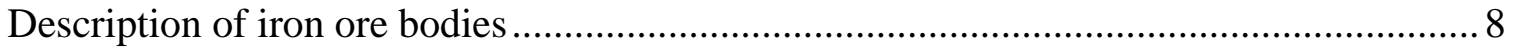

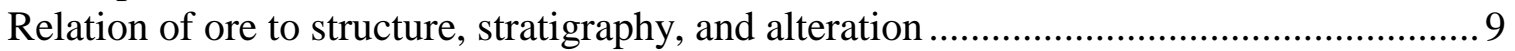

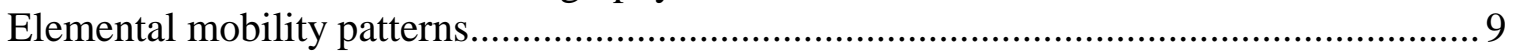

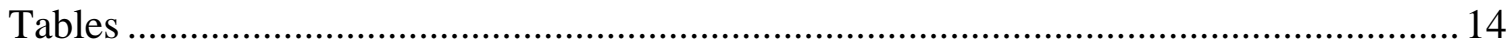

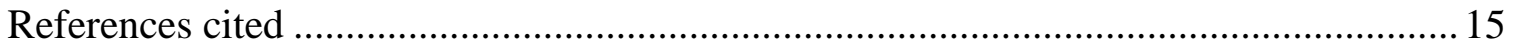

\section{Figures}

Figure 1: Location and setting of the Eagle Mountain iron deposits. ............................. 11

Figure 2: Reconnaissance geologic map of the eastern and central parts of the Eagle

Mountain mine area on topographic base......................................................... 12

Figure 3: Geologic map of the "phase I" area (located in figure 2). Numbered localities

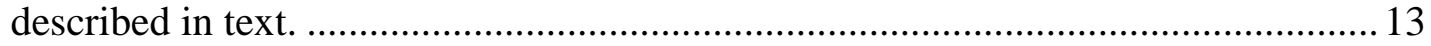

\section{Tables}

Table 1: Cobalt contents of pyrite in various iron ores of the Eagle Mountain district...14

Table 2: Approximate magnitude of $\mathrm{Fe}, \mathrm{Mg}$, and $\mathrm{Si}$ flux to form iron ore, dolomite, and vitreous quartzite, calculated per kilometer of depth. ....................14 


\section{Abstract}

This investigation of the Eagle Mountain Mine area, though cursory, revealed new structural, alteration, and stratigraphic relations. Eagle Mountain ores were previously an important source of iron to the western U. S. Ore (where fresh) is magnetite-pyrite rock forming two stratabound horizons virtually continuous for $11 \mathrm{~km}$.

Gneissic basement rocks are overlain by two sedimentary units, separated by unconformities. The lower unit contains carbonate rocks and quartzite; the "vitreous quartzite" of previous workers, however, is an alteration feature rather than a stratigraphic one. The upper unit contains thick conglomerates. This layered sequence of rocks is deformed into a west-plunging anticline. Intrusion by Jurassic quartz monzonite apparently followed this deformation.

Quartz monzonite forms a branching network of sills, some of which dilate the contact between the upper and lower sedimentary sequences. Intrusion resulted in extensive, mostly-anhydrous skarns, but stratabound iron ore is just as closely related to some other features: 1) regional alteration of quartz monzonite, with iron ore adjacent to little-altered rocks along the boundary between sodic and potassic domains, 2) the two unconformities, which apparently formed stratigraphic traps for precipitation of stratabound iron ores, 3) a north-facing monoclinal plane between folds, which was preferentially replaced.

Iron ore replaces a variety of host rocks along the two unconformities, forming massive to globular bodies, and its mineralogy correlates with deuteric alteration features, not anhydrous skarn. Its pyrite contains as much as $3 \%$ cobalt.

Iron was only one of five elements that showed mobility in this region on a scale that suggests basic crustal processes. The others in probable order of flux magnitude are silica, magnesium, sodium, and potassium, to form regionally distributed "vitreous quartzite", dolomite, and secondary feldspars, respectively. 


\section{Introduction}

The Eagle Mountain Mine of southeastern California (fig. 1) was by far the largest iron mine of the western U.S. from 1948 to 1982, feeding Kaiser Steel Corporation's Fontana steel mill and thence associated shipyards and auto plants. Total production was about $120 \times 10^{6}$ short tons of ore; yearly production reached $9 \times 10^{6}$ tons (Drossel, 1967; Dubois and Brummett, 1967; Thompson, 1992). Kaiser built its own 52-mile railroad to the mine and operated 100-car trains. From 1965 onward it ran a pelletizing plant, the world's largest when built. Ore trucks were as large as 150 tons. Employment eventually topped 1500. This operation was a significant factor in the economy of the region.

The mine, in the desert of the Eastern Transverse Ranges, consists of three open pits along a belt of deposits oriented WNW-ESE, extending $11 \mathrm{~km}$ across the northern end of the Eagle Mountains (fig. 1). Harder (1912) first mapped and described the deposits, but they were already subject to more than 100 claims, some based on an association of gold and base metal deposits with iron enrichment. Hadley (1945) mapped and described the deposits at the eastern end of the belt. The most recent comprehensive map and description are by Dubois and Brummett (1967), but the maps by Harder (with John L. Rich) have generally not been surpassed.

The deposits are thought to have formed in the Jurassic when this region was a magmatic arc. This arc is described by Tosdal and others (1989) and Busby-Spera and others (1990), and in the adjacent Palen Mountains by Fackler-Adams and others (1997). Tertiary structural modification of original paleogeographic relations is described by Richard (1993) and Powell (1993). Geologic mapping of the Eagle Mountains south of the study area is by Powell (1981).

The Eagle Mountain deposit has traditionally been considered a skarn deposit, formed by the intrusion of Jurassic granitoid rocks into older carbonate-bearing sequences. In many ways this characterization is apt, but relations described herein raise new questions of what iron skarn deposits really are, and how and when they form.

The impetus for this study comes from several separate considerations: 1) Certain aspects of new models for Fe-oxide-rich mineralization of the Olympic Dam type (e.g. Hitzman and others, 1993; Barton and Johnson, 1996) seem applicable to iron skarn deposits and need to be investigated; 2) the Eagle Mountain open pits are currently scheduled to become landfills for Los Angeles-derived trash, thus the deposits will eventually become concealed; and 3) the Tucson office of U.S. Geological Survey is conducting a study of a desert district including the Eagle Mountains for the Bureau of Land Management. The USGS is also a junior partner in a project on Fe-oxide-rich mineral deposits in the Center for Mineral Resources (Tucson), led by Mark Barton, University of Arizona. This study is intended to provide a stratigraphic and structural framework for subsequent detailed project work.

I thank Kaiser Ventures and Mine Reclamation Corporation, and Eagle Mountain staff Jeanette Roberts and Orlo Anderson for access, logistical support, and advice. My wife Jane Force assisted with field work, and advice in the field came from Mark Barton, Dennis Cox, and Gordon Haxel. Microprobe analyses of sulfide minerals were by Frank Mazdab. 


\section{Setting of iron ore}

The iron deposits are broadly stratabound and NNE-dipping, forming two horizons extending $11 \mathrm{~km}$ laterally in contact-metamorphosed sedimentary rocks. They roughly follow the contact of this sequence with porphyritic granitoid rocks of Jurassic age to the north. These vary in composition and texture but are generally referred to as quartz monzonites, and I will continue to do so.

Each ore zone ranges in thickness roughly from 10 to $100 \mathrm{~m}$ (Dubois and Brummett, 1967), separated by 50 to $100 \mathrm{~m}$ mostly of quartzite. Where fresh, mostly in the mines, ore consists of dense networks of magnetite and lesser pyrite in metamorphosed host rocks; in near-surface oxidized zones the ore mineralogy becomes hematite and gypsum. Near-surface oxidation is not described further in this paper.

The following description of features of the area is arranged in probable order of age.

\section{Stratigraphy}

The layered sequence of the study area consists of three main units--a gneissic basement, a lower sedimentary unit characterized by marble and quartzite, and an upper sedimentary unit characterized by conglomerate (fig. 2). Unconformities are thought to separate these units. All have been subjected to contact metamorphism, and partly for this reason their ages are uncertain.

Gneissic basement.--This unit, first noted by Harder (1912, p. 24), varies from nearlymassive coarse granitoid rocks through augen gneiss to finely layered gneiss. Refolded folds are characteristic but no effort was made to study these structures. Early folds are commonly isoclinal, and show a degree of deformation far greater than that of any other unit.

The nearly massive granitoid rocks of the basement show equigranular quartzplagioclase-orthoclase perthite intergrowths, contain primary clinopyroxene with other mafic minerals secondary, and contain minor allanite but lack sphene. In these characteristics they differ from otherwise-similar Jurassic quartz monzonites (described below).

The gneissic basement unit is locally altered to granular quartz-rock, as noted by Dubois and Brummet (1967, p. 1597). This alteration has produced a pseudostratigraphy, as noted below under "vitreous quartzite". Gneissic basement of the study area probably correlates with some of the Proterozoic meta-igneous rocks that form most of the Eagle Mountains south of the map area (Powell, 1981).

Lower sedimentary unit.-- This unit now consists largely of hornfels and granofels, but characteristically includes marble and quartzite (not including the "vitreous" or lower quartzite of previous workers). The unit is about $100 \mathrm{~m}$ thick along the main ore zone but is commonly thinner to the south. Quartzite (mostly the middle quartzite of Dubois and Brummett, 1967) in this unit shows detrital textures, and locally is feldspathic. The basal unit is the schistose arkose of previous authors. 
The marble is mostly dolomitic, but is commonly calcareous in the southern part of the map area, and elsewhere includes darker argillaceous, slightly calcareous beds and anastomosing bleached calcareous zones. Dolomite replaces calcite except where veined by late calcite. Near iron-ore horizons, the marble contains alteration minerals such as serpentine.

The lower sedimentary unit is probably Proterozoic, based on correlations with units in the San Bernardino Mountains and the Baker area (R. E. Powell, oral comm., 1997) but could possibly be Paleozoic.

Upper sedimentary unit.-- This unit also includes hornfels and granofels, but is characterized by conglomerate beds each typically tens of meters thick. Cobble conglomerate predominates. Clasts include quartzite (but not "vitreous quartzite"), feldspar crystals, granofels and hornfels, garnetite, marble, granitic rocks, and gneiss. Clearly the present nature of the clasts is a function of contact metamorphism of the conglomerate. Clast rounding is extremely variable; granitic rocks and gneiss tend to be more rounded. Along-strike variations also occur; gneiss clasts are more common to the NW, marble to the SE. Conglomerate is interbedded with laminated fine sediments, and forms moderately well-sorted beds, each characterized by its own modal grain size.

The thickness of this unit is unknown, because it extends northward out of the map area, is extensively intruded by quartz monzonite sills, and is deformed. It seems likely to be very thick north of the main ore zone but to be thin or absent south of it.

The base of the upper unit is undefined; at only one locality did the base of the conglomerate itself seem unconformable. The clast assemblage of conglomerate, however, shows that both lower units were indurated at the time of deposition, suggesting an unconformity separating conglomerate from marble and quartzite. The age of the upper unit is unknown; the permissive age range currently is Proterozoic to Mesozoic.

My upper unit is approximately equivalent to the upper quartzite of DuBois and Brummett (1967), a misleading designation, as little true quartzite is present in it. Conglomerates were noted as characteristic of upper stratigraphic levels by both Harder (1912) and Hadley (1945).

"Vitreous quartzite".--The vitreous or lower quartzite of earlier workers (Harder, 1912; Hadley, 1945; DuBois and Brummett, 1967) is pseudostratigraphic in part, formed by replacement of gneiss and marble. As the name implies, its appearance is that of coarsegrained quartz that is granular, but no detrital texture can be recognized; instead the quartz is commonly platy. The stratigraphic position of marble in the western part of the study area is occupied by "vitreous quartzite" in the eastern part, and throughout the area thick subhorizontal zones of "vitreous quartzite" in gneissic basement cut gneissic foliation but locally show ghosts of replaced folds and foliation.

The only detailed mapping I undertook was in the "phase I" area intended to be the first landfill site. Figure 3 shows multiple thick zones of subhorizontal "vitreous quartzite" in gneiss. Gneissic banding is locally cut by "vitreous quartzite" as at locality 1 , and this quartzite locally shows incomplete replacement of gneissic structure as at localities 2 and 3 . The contacts are generally tight and gradational over $10-15 \mathrm{~cm}$. "Vitreous quartzite" itself shows a tectonic lineation trending NE, but it may be inherited.

Some sedimentary quartzite was probably present at the lower quartzite horizon, and pseudomorphed by "vitreous quartzite" that also replaced carbonate and gneissic 
rocks. Thus the volume of "vitreous quartzite" gives a maximum value for introduced silica.

\section{Old structures}

My mapping of the district (fig. 2) is reconnaissance in nature, intended to provide a structural framework for subsequent more detailed study. My observations are centered on the mine's road network, which provides access to otherwise-inaccessible areas, but in this area mapping is hampered by voluminous mine dumps.

The layered sequence of the study area is deformed into an open anticline (figs. 1, 2 ) that extends the entire 12-km length of the study area. The anticlinal zone is complex, and includes several synclines, including some in and north of the main ore zone. Several faults are probably younger.

The anticline, noted by Harder (1912) and subsequent workers, exposes a core of gneissic basement, unconformably flanked by the lower sedimentary unit. Plunge of this structure to the WNW is shown where the lower sedimentary unit wraps around the gneissic basement toward the west end of the study area (figs. 1, 2).

This plunge implies greater paleodepths toward the east end of the study area (if initial plunge was zero). However, some stratigraphic complexities would seem to require cross-folding or pre-fold faults. My inability to resolve all such structures has resulted in omission of the westernmost part of the belt in the geologic map (fig. 2). Quartz monzonite sills conform to both folds, but probably postdate the folds, based on the distribution of deuteric features relative to structure.

\section{Intrusions}

The most voluminous intrusive igneous rocks in the study area are the Jurassic quartz monzonites. These form branching sills from tens to hundreds of meters thick, as well as numerous smaller dikes. In some sense they extend around the anticlinal structure so that they form parts of the southern and northern margins of the map area (figs. 1,2). A main locus of quartz monzonite intrusion is between the lower and upper sedimentary sequences, though a few remnants of conglomerate of the upper sequence are found south of this sill and suggest a dilational intrusion geometry. Because the predominant strike of the upper sedimentary sequence north of this sill is more northwesterly than the lower sequence south of it (which strikes WNW), this sill may have intruded a faulted unconformity.

The Jurassic quartz monzonite where fresh consists of purplish perthitic phenocrysts in an equigranular 1-2 mm matrix of plagioclase, K-spar, hornblende, biotite, quartz, and sphene. Clinopyroxene is a locally preserved primary phase. Locally syenitic perthite-rich dikes are common. Chilled contacts against sedimentary rocks are not very common but have been observed. Deuteric (uralite-epidote-carbonate) alteration is regionally ubiquitous in the quartz monzonite; the mineralogy and distribution of variations of such alteration in the study area is described below.

The sill-like nature of these bodies between continuous country rocks was 
recognized by Harder (1912) and Hadley (1945). DuBois and Brummett (1967) viewed the country rocks north of the iron deposits as xenoliths in quartz monzonite.

A few dikes of other intrusive rocks are present in the study area (shown only on fig. 3). These include NW-striking steep black dikes altered to chlorite and epidote, and steep porphyry dikes that are not obviously altered but locally are associated with copperoxide staining. Harder (1912) describes other intrusive rock types at greater length.

\section{Metamorphism}

Mostly-anhydrous contact metamorphism is presumably responsible for the formation of coarse marble, but is also obvious in the northern part of the study area, where fine-grained rocks and poorly sorted sandstones have been recrystallized to hornfels and granofels. Clinopyroxene, garnet, epidote, clinozoisite, and potassium feldspar are common metamorphic minerals in these rocks. Locally, hornblende, wollastonite, and sphene have been recorded, and perhaps muscovite and phlogopite belong to this association in some localities. In conglomerate, garnet tends to rim clasts, especially carbonate, whereas clinopyroxene, epidote, and potassium feldspar replace matrix. Variations in contact-metamorphic mineral assemblages with distance from intrusions were not observed in the northern part of the study area, perhaps because quartz monzonite sills are so ubiquitous there. More detailed study of this metamorphism therefore did not seem productive; an important consequence of this metamorphic stage is that the rocks became brittle and impermeable.

\section{Alteration}

My study of alteration was centered on the Jurassic quartz monzonite, which shows an unexpected pattern of alteration, quite unlike one might expect in a conventional skarn deposit. That is, quartz monzonite alteration is not against reactive country rocks, as it would be in endoskarn, but rather widely distributed and most apparent well away from mineralized rock.

Structurally within about about $300 \mathrm{~m}$ of iron ore horizons, quartz monzonite is typically nearly fresh, to a degree that is unusual for this rock unit in mountain ranges to the north and east. Primary clinopyroxene, hornblende, biotite, perthitic potassium feldspar, plagioclase, and sphene are preserved in quartz monzonite adjacent to iron ore. Bleached steep cross-cutting zones 1-5 m thick in which albite, epidote, chlorite, and sericite permeate the rock constitute only about $10 \%$ of these areas.

At greater distances to the north, quartz monzonite generally shows pervasive replacement of plagioclase by albite, with some replacement of primary mafic minerals by chlorite and actinolite. Potassium feldspar, however, is generally not replaced, suggesting albitization displaces calcium more readily than potassium here. In such zones of pervasive albitization, thin zones of even more intense alteration to albite, epidote, chlorite, and actinolite may together constitute $20-30 \%$ of the rock area.

Potassic alteration is common in quartz monzonitic rocks in and south of the iron 
ore horizons. A few rocks contain both secondary albite and potassium feldspar, the latter locally poikiloblastic. In sedimentary rocks, abundant phlogopite suggests potassic alteration.

Other types of alteration in the layered sequence are also extensive. A metasomatic origin of "vitreous quartzite" was described above. Dolomitization is extensive but more complete on the north limb of the anticline than on the south, i.e. the distribution of dolomite and iron ore are the same. Therefore dolomitization is probably a product of the same alteration that produced iron ore.

More local alteration features vary between units: chlorite is most common in gneissic basement, phlogopite-epidote or serpentine in carbonate rocks, and actinolite in quartzite. Hornfels and metaconglomerate seem to be little altered, possibly due to the impermeability conferred by earlier contact metamorphism.

\section{Description of iron ore bodies}

Iron ore of the district where unweathered is nearly homogeneous in some important respects. As described in above-listed literature, the main bodies of ore are massive replacements, containing varying proportions of gangue assemblages and inclusions of host rocks. Lesser ore bodies form veins and layers in sedimentary host rocks and locally in quartz monzonite.

Ore is basically magnetite-pyrite rock with minor apatite (Harder, 1912) and chalcopyrite (Dubois and Brummett, 1967). Pyrite ranges up to $10 \%$, averaging 3 to $4 \%$ (Hadley, 1945). The most abundant gangue minerals are dolomite, serpentine, and tremolite in varying proportions. Alteration minerals in close proximity to ore include epidote, phlogopite, chlorite, clinozoisite, and minor tourmaline, in addition to abovenamed minerals, varying with type of wallrock.

My own study of ore adds little except in the following respects. Magnetite ore commonly shows globular replacement textures with gangue selvages, especially serpentine. Locally, as in lower ore of the central pit, it contains $10-50 \%$ platy pyrite in radial masses, and minor scapolite.

In a few places, ore shows mutually cross-cutting relations with quartz monzonite, suggesting multiple episodes of intrusion and ore formation. However, the gangue mineralogy of ore shows little relation to the mostly-anhydrous contact-metamorphic mineral assemblages of the district, and much more resemblance to the regional alteration assemblages.

Frank Mazdab did microprobe analyses of pyrites from my samples of Eagle Mountain ores (Mazdab and Force, 1998). These analyses show that pyrite commonly contains cobalt in the range 1.5 to $3 \%$, with high but variable ratios of cobalt to nickel. The variability of cobalt values is high even in samples taken at the same outcrop. Table 1 shows the variability as a function of ore horizon and location. 


\section{Relation of ore to structure, stratigraphy, and alteration}

The distribution of iron ore along the margin of quartz monzonite to the north, and to anhydrous contact metamorphism along this margin, has been noted by all previous workers and forms the basis of classifying the Eagle Mountain deposits as iron skarns. A weakness in this spatial relation lies in the absence of iron ores in the same host rocks along their margin against quartz monzonite to the south. Accordingly, several other factors that seem to control distribution of iron ore are explored below.

Ore is so stratabound that it has been treated as an element of the stratigraphy along its entire 11-km length (e.g. Dubois and Brummett, 1967). The explanation for this odd distribution may be unconformities in the sequence of host rocks. The apparent presence of two unconformities in the sedimentary sequence (between basement and the lower sedimentary sequence, and between the lower and upper sedimentary sequences) is reflected in the two ore horizons at almost the same stratigraphic positions. Lower ore departs from the lower unconformity only by the thickness of "schistose arkose" where present, and upper ore may not depart from the upper unconformity at all, even where the quartz monzonite intrusive is absent. It is tempting to think of ore as being localized along the unconformities, perhaps by some sort of stratigraphic trapping, as well as by intrusive activity.

The iron ore bodies of the study area are also localized along a north-facing limb of the anticline. Harder (1912) and subsequent workers noted that mineralization is far less on the south limb of the anticline, except perhaps in the area of Iron Chief mine (fig. 1). Indeed, a marked decrease in ore occurs at the point where host rocks begin to depart from the monoclinal limb. In detail, even the Iron Chief proves no exception; it formed along the south limb of a satellitic syncline within the anticlinal zone, i.e. it too is northfacing. Thus ore is intricately controlled by folds at the scale of tens of kilometers.

Iron mineralization shows no direct relation to either sodic alteration to the north or potassic alteration to the south, but the main ore zone occupies a boundary between the two alteration types, in a zone of fresher rocks between them. Within this zone, iron distribution is controlled by stratigraphic and structural traps. Apparently iron mobility was related to sodium and potassium mobility, but the traps for alkalies and iron were independent. Zones of intense alteration in less-albitized quartz monzonite adjacent to iron ore may be the conduits that connected the two systems chemically.

In sum, it seems likely that quartz monzonite intrusive contacts are one of

probably four factors involved in ore distribution. Ore probably formed along a boundary between regional alteration domains following quartz monzonite intrusion, where unconformity-controlled stratigraphic traps in favorable host sequences had a particular planar orientation.

\section{Elemental mobility patterns}

The geology of the study area requires large-scale mobility of a suite of major elements. Among these are 1) sodium to form albite, 2) potassium to form secondary potassium feldspar, 3) iron to form the iron deposits, 4) silica to form "vitreous 
quartzite", and 5) magnesium to form dolomite, mostly on the northern limb of the anticline.

My impression based on areas and intensity of alteration is that secondary albite is much more abundant than that of potassium feldspar formed by alteration, and thus that sodium mobility far exceeded potassium mobility. This is ironic considering the intriguing suggestion of DuBois and Brummett (1967) that the "purple" K-spar is secondary and requires potassium metasomatism in the northern part of the study area. The feldspar they described is perthitic and thus primary, and most of the secondary potassium feldspar in the northern part of the study area is associated with anhydrous contact metamorphism rather than regional alteration. The best evidence of potassium mobility associated with alteration is in the southern part of the study area.

Back-of-the-envelope calculations (table 2) of the volumes and concentrations of iron, magnesium, and silica required to form iron ore, dolomite, and "vitreous quartzite", respectively, in the study area (per unit of depth), suggest that the number of mobile moles for each element is in the same order of magnitude, though greater for silica than for iron and magnesium. The calculation for sodium is uncertain because sodium enrichment extends northward far outside the study area, but even the study area could supply enough sodium to match iron. Potassium is similarly unconstrained, but the study area itself does not show as much potassium as iron mobility. Thus of the suite of five elements considered here, iron was among the least mobile. All five elements seem to have found traps independent of each other. Formation of the Eagle Mountain deposits must have been a by-product of extensive crustal processes, more extensive than the term "skarn" generally implies. 


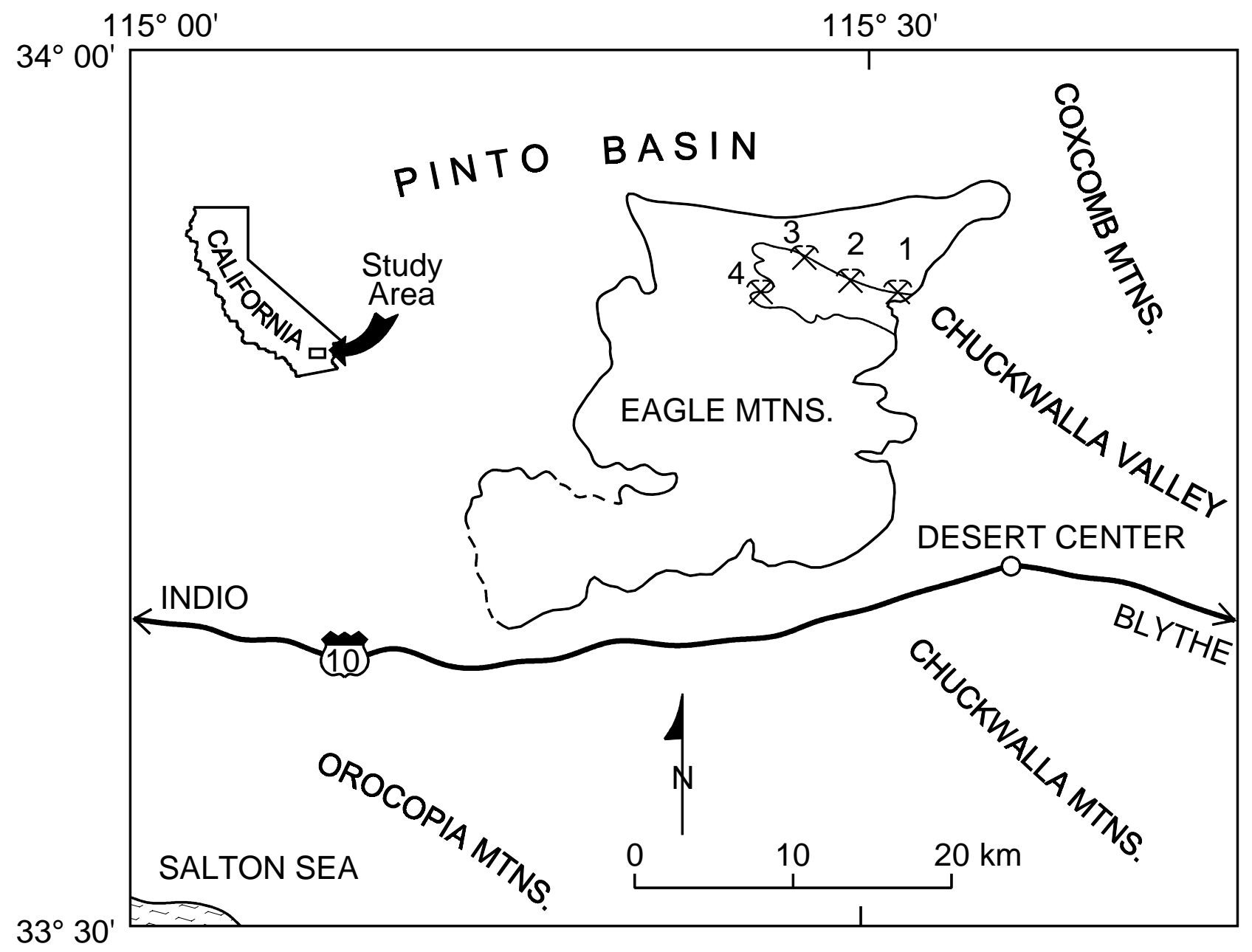

Figure 1. Location and setting of the Eagle Mountain iron deposits. Line through mines (after Jennings, 1967) represents approximate top of the lower sedimentary unit, locally the locus of upper ore horizon. Numbered mines: Eagle Mountain mine includes 1. Eastern pit, 2. Central pit, and 3. Black Eagle pits. Iron Chief mine is 4. 


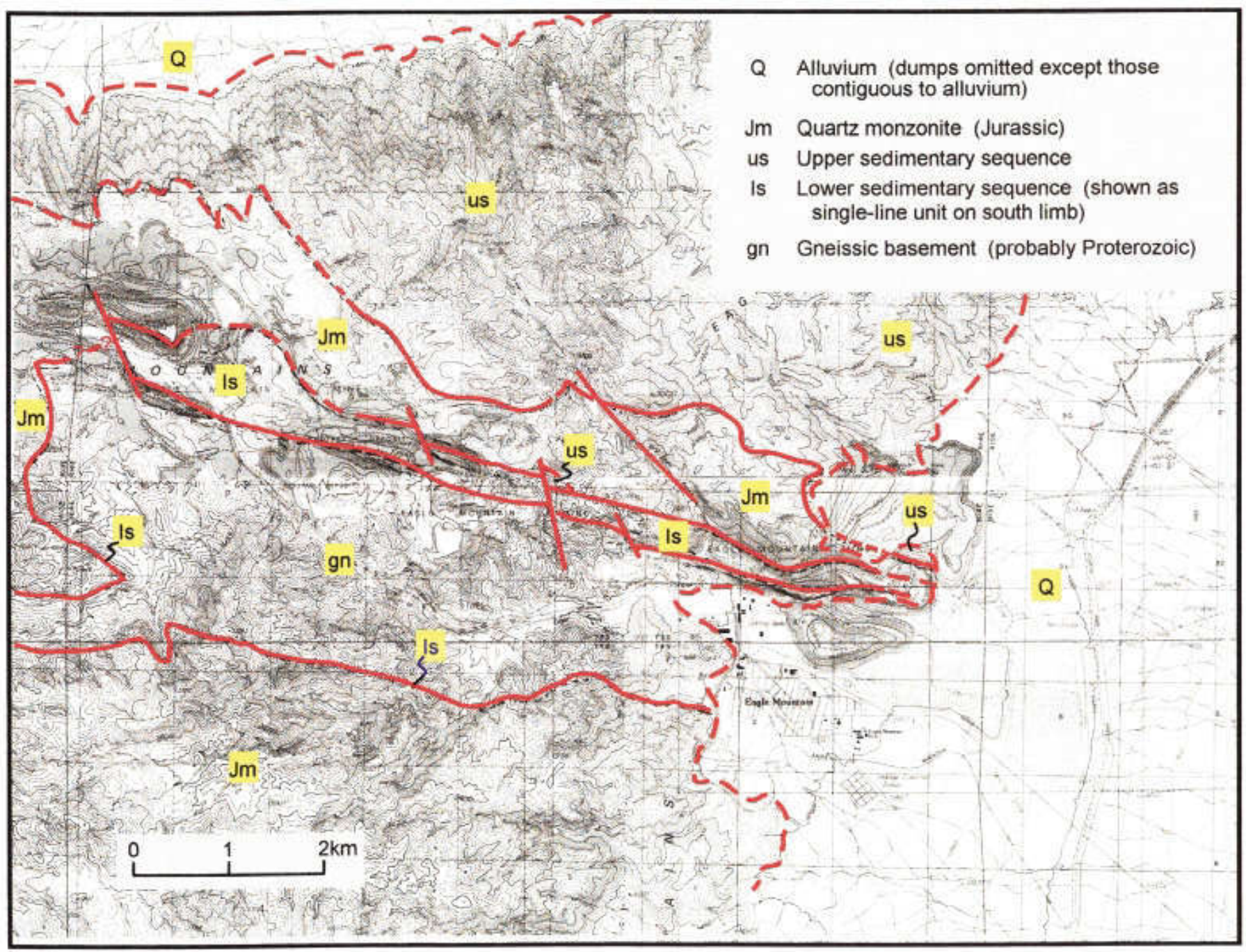

Figure 2. Reconnaissance geologic map of the eastern and central parts of the Eagle Mountain mine area at 1:48,000, on topographic base. 


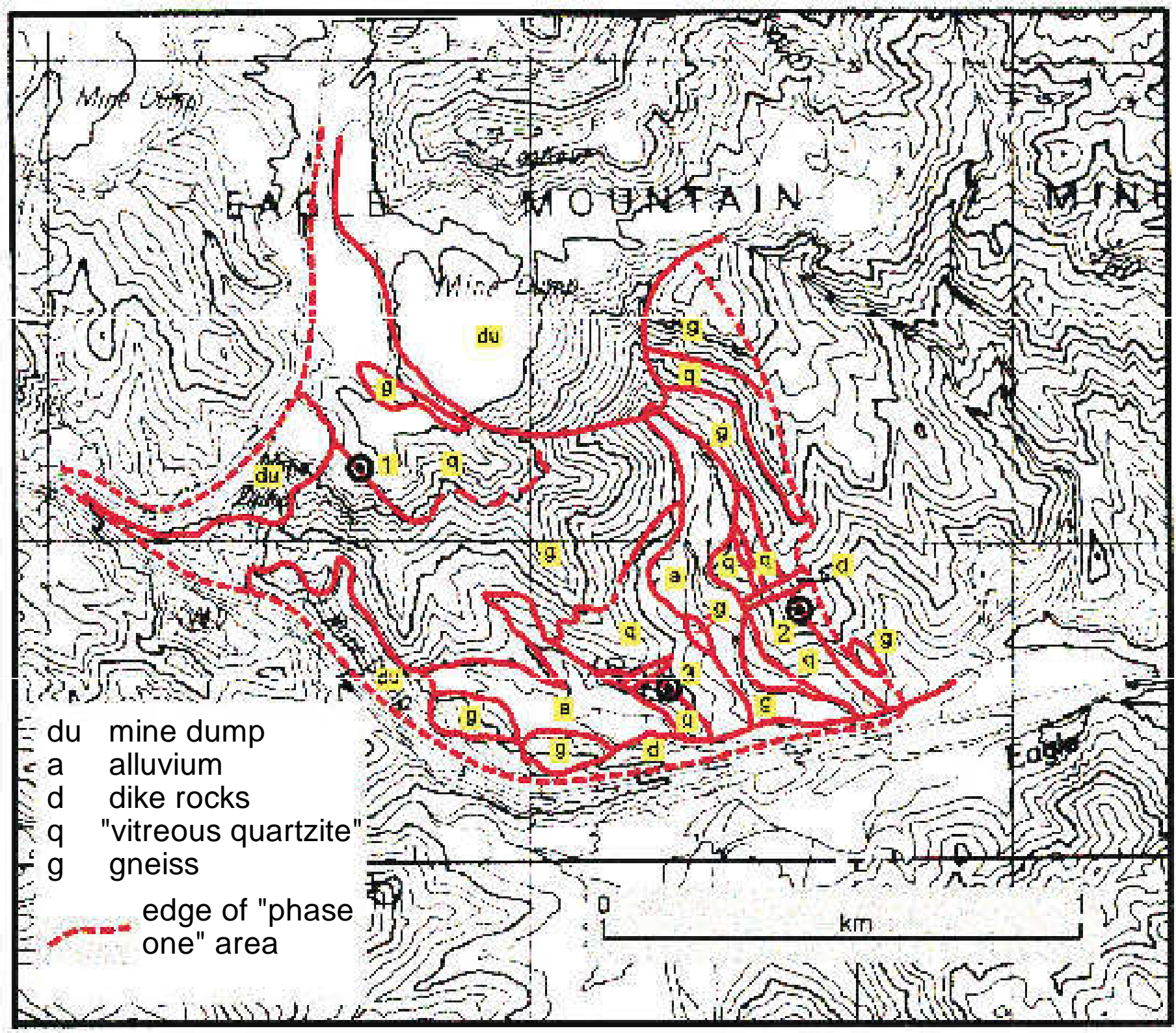

Figure 3. Geologic map of the "phase I" area (located in figure 2). Numbered localities described in text. 


\section{Tables}

Table 1.-Cobalt contents of pyrite in various iron ores of the Eagle Mountain district $(\mathrm{N}=$ number of samples, values in wt.\% Co). See also Mazdab and Force, 1998.

\begin{tabular}{|l|l|l|l|}
\hline & Eastern pit & Central pit & $\begin{array}{l}\text { Black Eagle } \\
\text { (western) pit }\end{array}$ \\
\hline Upper ore & $0-3.21 \%, \mathrm{n}=16$ & oxidized & $0-2.14 \%, \mathrm{n}=11$ \\
\hline Lower ore & $0-2.17 \%, \mathrm{n}=7$ & $0-2.94 \%, \mathrm{n}=9$ & oxidized \\
\hline
\end{tabular}

Table 2.-- Approximate magnitude of $\mathrm{Fe}, \mathrm{Mg}$, and Si flux to form iron ore, dolomite, and vitreous quartzite, calculated per kilometer of depth. For silica the volume of replaced original sedimentary quartzite in the lower quartzite horizon (not part of flux) is balanced against the silica introduced into basement rocks (unmeasured flux), i.e. the volume used is that of the "vitreous quartzite" of previous maps. Constraints on fluxes for $\mathrm{Na}$ and $\mathrm{K}$ discussed in text.

\begin{tabular}{|l|l|l|l|l|}
\hline $\begin{array}{l}\text { Element and } \\
\text { atomic wt. }\end{array}$ & $\begin{array}{l}\text { Enrichment } \\
\text { thickness }(\mathrm{m})\end{array}$ & $\begin{array}{l}\text { Implied } \\
\text { enrichment } \\
\text { tonnage }\left(\mathrm{x} 10^{6}\right)\end{array}$ & $\begin{array}{l}\text { Enrichment } \\
\text { grade (as wt.\% } \\
\text { added element) }\end{array}$ & $\begin{array}{l}\text { Tonnes of } \\
\text { element added } \\
\left(\mathrm{x} 10^{6}\right)\end{array}$ \\
\hline $\mathrm{Fe}(55.85)$ & 50 & 2000 & 25 & 550 \\
\hline $\mathrm{Mg}(24.32)$ & 100 & 2700 & 20 & 540 \\
\hline $\mathrm{Si}(28.09)$ & 100 & 2700 & 40 & 1050 \\
\hline
\end{tabular}




\section{References cited}

Barton, M. D., and Johnson, D. A., 1996, Evaporitic-source model for igneous-related Fe oxide-(REE-Cu-Au-U) mineralization: Geology, v. 24, p. 259-262.

Busby-Spera, C. J., Mattinson, J. M., Riggs, N. R., and Schermer, E. R., 1990, The Triassic-Jurassic magmatic arc in the Mojave-Sonora deserts and the SierranKlamath region: similarities and differences in paleogeographic evolution, in Harwood, D., and Miller, M., eds., Late Paleozoic and Mesozoic paleogeographic relations, Klamath-Sierra and adjacent regions: Geological Society of America Special Paper 225, p. 325-337.

Drossel, M. R., 1967, Kaiser's Eagle Mountain project; from pit to premium pellet: Engineering and Mining Journal, June 1967, p. 45.

Dubois, R. L., and Brummett, R. W., 1967, Geology of the Eagle Mountain Mine area, in Ore Deposits of the United States 1933-1967 (the Graton-Sales Volume), part II, J. D. Ridge, eds: American Institute of Mining and Metallurgical Engineers, p. 15921606.

Fackler-Adams, B. N., Busby, C. J., and Mattinson, J. M., 1997, Jurassic magmatism and sedimentation in the Palen Mountains, southeastern California: Implication for regional tectonic controls on the Mesozoic continental arc: Geological Society of America Bulletin, v. 109, p. 1464-1484.

Hadley, J. B., 1945, Iron-ore deposits in the eastern part of the Eagle Mountains, Riverside County, California: California Division of Mines Bulletin 129A, 24 p.

Harder, E. C., 1912, Iron-ore deposits of the Eagle Mountains, California: U. S. Geological Survey Bulletin 503, 81 p.

Hitzman, M. W., Oreskes, N., and Einaudi, M. T., 1992, Geological characteristics and tectonic setting of Proterozoic iron oxide (Cu-U-Au-REE) deposits: Precambrian Research, v. 58, p. 241-287.

Jennings, C. W., 1967, Salton Sea sheet, Geologic Map of California: California Division of Mines and Geology, 1:250,000.

Mazdab, F. K., and Force, E. R., 1998, Comparison of Co and Ni contents in sulfides from Fe-oxide-(Cu-Au-U-REE) occurrences with other hydrothermal and magmatic systems: Geological Society of America Abstracts with Programs v. 30, p. 369. 
Powell, R. E., 1981, Geology of the crystalline basement complex, Eastern Transverse Ranges, southern California: unpub. Ph. D. thesis, California Institute of Technology, Pasadena, $441 \mathrm{p}$.

-----, 1993, Balanced palinspastic reconstruction of pre-Late-Cenozoic paleogeology, southern California: Geologic and kinematic constraints on evolution of the San Andreas fault system: Geologic Society of America Memoir 178, p. 1-106.

Richard, S. M., 1993, Palinspastic reconstruction of southeastern California and southwestern Arizona for the middle Miocene: Tectonics v. 12, p. 830-854.

Thompson, J. V., 1992, The Eagle Mountain iron ore mine; how great it was: Skillings' Mining Review, May 9, 1992, p. 4-15.

Tosdal, R. M., Haxel, G. B., and Wright, J. E., 1989, Jurassic geology of the Sonoran Desert region, southern Arizona, southeastern California, northernmost Sonora: construction of a continental-margin magmatic arc, in Jenny, J. R., and Reynolds, S. J., eds., Geological evolution of Arizona: Arizona Geological Society Digest v. 17, p. 397-434. 